\title{
Instrument for evaluating care given by undergraduate nursing students to people with wounds
}

\author{
Instrumento para avaliar o cuidado de graduandos de enfermagem à pessoa com ferida \\ Instrumento para evaluar el cuidado de graduandos de enfermería a la persona con herida
}

Roberta Kaliny de Souza Costa ${ }^{1}$, Gilson de Vasconcelos Torres², Marina de Góes Salvetti ${ }^{3}$, Isabelle Campos de Azevedo ${ }^{4}$, Maria Antônia Teixeira da Costa ${ }^{5}$

\footnotetext{
${ }^{1}$ Associate Professor, University of the State of Rio Grande do Norte, Caicó, RN, Brazil.

${ }^{2}$ Titular Professor of the Nursing Department, Federal University of Rio Grande do Norte, Natal, RN, Brazil.

${ }^{3}$ Professor, Department of Medical and Surgical Nursing, School of Nursing, São Paulo University, São Paulo, SP, Brazil.

${ }^{4}$ Master's Student, Federal University of Rio Grande do Norte, Natal, RN, Brazil.

${ }^{5}$ Professor, University of the State of Rio Grande do Norte, Mossoró, RN, Brazil.
}

\begin{abstract}
Objective: The aim of this study was to present the process of construction and validation of an instrument for evaluating the care provided to people with wounds, to be used with undergraduate nursing students. Method: methodological study, with quantitative approach, using the Delphi technique in two rounds, the first with 30 judges and the second with 18 . The analysis was made with Kappa coefficient $\geq 0.80$, and content validity index greater than $>0.80$, also using the Wilcoxon test for comparison of the indices between the rounds. Results: It was found that of the 20 categories of the instrument, 18 presented better scores in the second Delphi round. Scores were greater in the second round in seven of the ten evaluation categories. Conclusion: Based on the evaluation by the judges, a version of the instrument was defined with adequate indices of agreement and validity, which will be able to help in evaluating care of people with cutaneous injury given by undergraduate nursing students.
\end{abstract}

DESCRIPTORS

Wounds and Injuries; Nursing Care; Validation studies; Students, Nursing. 


\section{INTRODUCTION}

Injuries are a frequent problem in health services, weakening and often incapacitating the individual and adversely affecting quality of life, as well as causing great impact for the health sector and burden on public expenditure ${ }^{(1-2)}$.

Healthcare for these patients requires systematized care, provided by a multi-professional team and oriented by healthcare protocols, availability of material resources and pharmacological products, coordination and interaction between the levels of complexity of healthcare, and effective participation by patients, members of family, and caregivers ${ }^{(3)}$.

Nursing professionals have an important role in providing care for these patients, evaluating and diagnosing the problem, planning and executing treatment at home and in the health services ${ }^{(4)}$, performing a series of activities that require preparation during graduation, as well as continuous and renewed theoretical learning/qualification and practice for their development.

The preparation of the future nurse is decisive for the quality of the assistance given to these patients, and should be evaluated based on construction and use of instruments for measurement that are able to characterize the student's theoretical and practical knowledge in the execution of certain tasks related to this type of care.

In nursing, there has been a scarcity of studies evaluating training in competencies and abilities, and also of the use of measurement instruments based on situations of reality, which reproduce the routine of the activities of the nurse in professional life and provide evaluation of the student's cognitive, psycho-motor and affective learning - all three dimensions are indispensable to realization of full and humanized care.

The instruments to be adopted in the performance evaluation of care provided by the undergraduate nursing student should be validated, grounded on scientific studies, and include the systematization of care, as a means of ensuring consistent, effective conduct in teaching and in clinical practice ${ }^{(5)}$.

We emphasize the shortage, in the literature, of available measurement tools for evaluation of nursing students' care of a person with a cutaneous lesion, especially those based on the opinion/agreement of the nurses involved in undergraduate teaching and in healthcare for this population.

In this context, this study present the process of construction and validation of an instrument, to be applied to undergraduate nursing students, for evaluating care provided to persons with cutaneous injury.

\section{METHOD}

This was a methodological study, with a quantitative approach, to present the process of construction and validation of a structured observation routine, of the 'checklist' type, to evaluate the care provided by undergraduate nursing students to people with injuries, assessed by specialist judges, using the Delphi technique, demarcated in two rounds.

This technique comprises a tool used in validation of survey content, and in construction and adaptation of mea- surement instruments, based on obtaining opinions from experienced professionals, also referred to as specialist judg$\mathrm{es}^{\left({ }^{(6)}\right.}$, and establishing degrees of consensus between them.

The theoretical element of the procedure in developing the instrument involved, initially, a search for the items that were representative of the construct under investigation (areas of skill that were relevant in nursing care for a person with a skin lesion), through an integrative review of the literature in healthcare protocols, scientific articles, dissertations and thesis.

From this process of analysis of the literature, the items of interest for evaluating the care provided by an undergraduate student to an injured person were extracted, and classified under these domains:

1) Initial observations (items: initial care, and hygienic cleaning of the hands).

2) Evaluation of the person and of the skin injury (items: anamnesis; identification of risk factors; physical examination; vital signs; evaluation of pain; assessment of the lesion; identification of signs of infection; identification of the need for any complementary examinations, and arranging for them to happen).

3) Care for the injury and for the perilesional skin (items: clean the injury; bandaging; evaluate the need for debridement; indicate coverage);

4) Referrals and orientations for the injured person and family member/caregivers (items: educational action; identify the injured person's needs for any referrals, and arrange them).

5) Registry and documentation (items: record of clinical assessment; record of assessment of the lesion).

6) Final observations (items: organize the environment; hygienic treatment of hands after care).

After deciding the items on the 'checklist', the next step was to describe them, followed by an explanation adopted as parameter for evaluation of the procedure carried out by the student. This resulted in a first version of the instrument, and this was submitted to consideration by a body of judges, with the objective of verifying evidence of validity of content.

This version of the checklist was submitted, in the period January through March 2013, to specialist judges with experience in the subject, who made the first evaluation on the checklist - the first Delphi round. After the first evaluation by the judges, and inclusion of the suggestions presented, the checklist was reformulated, and the second evaluation of the reformulated version - the second Delphi - was carried out between May and July of the same year, aiming to refine the opinions of the panel of specialists, seek improved levels of consensus, and thus improvement of the measurement instrument.

The nurses to act as judges of the instrument were selected using the advanced research tool under the subject 'wound' on the Lattes platform of the National Scientific and Technological Development Council (Conselho Nacional de Desenvolvimento Científico e Tecnológico, or CNPq).

147 professionals were selected based on the following criteria for inclusion: Nurses of any nationality; persons holding doctorates and masters' degrees in the broad area of concentration of health sciences; persons with activity in 
undergraduate teaching; and persons with scientific activity or production in the area of wounds in the last five years.

The nurses selected were contacted by email and invited to take part in the investigation as judges, by a letter of invitation stating the objectives and the methodology of the study, with an access link to the form for evaluation of the instrument - built in Google Docs (now known as 'Drive' at docs.google.com) and with the Free and Informed Consent Form (Termo de Consentimento Livre e Esclarecido, or TCLE).

The form sent to the judges for evaluation of the instrument was in two parts. The first asked questions on the participants themselves - included questions on age, gender, professional qualification, professional experience, and time of experience in teaching and in healthcare. The second part was the checklist format for structured observation, with 20 items for assessment of the theoretical knowledge and technical abilities of undergraduate nursing students when providing care for a person with an injury.

The judges were asked to evaluate the attributes chosen, according to their 'appropriateness' in relation to the following aspects: Utility/relevance; consistency; clarity; objectivity; simplicity; ability to be executed in practice; up-todate-ness; vocabulary; precision; and as to the order of the items in terms of instruction. When a judge found an item to be inappropriate or inadequate, he or she was encouraged to present reasons and suggestions, so that the items could be re-written, modified and improved.

The degree of relevance of the items was obtained by agreement between observers (and from variations between opinions of the same observers at different times) by means of the Kappa index ( $\kappa)$, intermediated by the Online Kappa Calculator $^{(7)}$, and through the Content Validity Index (CVI).

The Kappa coefficient measures the proportion of agreement between observers due to chance, in relation to the classification of a group of items in a given number of categories. ${ }^{(8)}$ It varies from 'minus 1' to 'plus 1' - so that, the closer it is to 1 , the greater is the level of agreement between the observers.

The CVI is an index that makes it possible to assess the degree of agreement between judges on certain aspects of an instrument and of its items, individually, based on a measurement of proportion or percentage. This is calculated based on the division of the number of judges who judged the item as appropriate by the total of judges (the CVI for each item). For evaluation of the instrument as a whole, the CVI can be calculated as the ratio between the total number of items considered to be relevant by the judges, and the total number of items ${ }^{(9)}$.

In the first round of evaluation of the checklist by the judges, the following levels of agreement were was defined as 'good', and adopted as a criterion of acceptance, greater than or equal to 0.61 for Kappa, and greater than 0.75 for the CVI.

The conclusion of the first process of analysis generated a version with alterations to the content of the initial instrument, based on the comments and suggestions of the judges, and pointed to the need for a new evaluation of the checklist. In the second round, the 30 nurses that participated in the first analysis were invited to continue the evaluation of the reformulated instrument. Of these, 18 agreed to continue participating in the investigation as judges (i.e. in the second Delphi round).

The process of submission, composition and criteria for evaluation of the instrument by the committee of specialists in the second round of opinions followed the same procedures adopted in the initial analysis.

The data collected were organized in a spreadsheet, and subsequently exported to a statistical software. After input and tabulation, the information was analyzed using descriptive and inferential statistics, with absolute and relative frequencies and application of the Wilcoxon test, adopting a significance level lower than 5\%.

In the second round of evaluations, the aim was to increase the scores in relation to the initial evaluation, adopting as acceptable a level of agreement greater than or equal to 0.80 for the Kappa index and above 0.80 for the IVC. Thus, the results below present the data of the evaluation of the second Delphi round in relation to the first, indicating, based on the comparison, evidences of improvement in the checklist, based on the values of Kappa and CVI obtained in the general analysis and for each item of the instrument.

The study was submitted and approved while Resolution 196/96 of the National Health Council was in effect, and has as its ethical governance Resolution 466/12 ${ }^{(10)}$. It was sent to the Research Ethics Committee of the Onofre Lopes University Hospital (CEP-HUOL), and its execution was authorized by approval opinion $\mathrm{n}^{\circ} 181.037$ (CAAE: 11090212.2.0000.5292), homologated on December 22, 2012.

\section{RESULTS}

The majority of the judges that took part in the investigation were female, both in Delphi round 1 (80\%) and in Delphi round $2(77.8 \%)$, and predominantly aged above 40 in both rounds (33.3\%, and 38.9\%, respectively).

In both Delphi rounds, the majority of the nurses had doctorate degrees (76.7\% and 83.3\%), had experience in teaching and in healthcare (93.3\% and 94.4\%). Their place of work was primarily in the Southeastern Region of Brazil (56.7\% and 39.9\%), followed by the Northeast $(20 \%$ and $27.8 \%)$. They primarily had worked in teaching between 1 and 20 years (73.4\% and 61.1\%), with experience in healthcare predominantly of between 1 and 10 years (40\% and $33.2 \%$ ).

In the evaluation of the 20 initial categories of competition of the instrument relating to nursing care for an injured person, it was found that 18 presented better scores in the Second Delphi round, one maintained the same scores as in the previous round ('carries out educational actions'), and in one other the score was reduced (referral of the injured person), but within the established level.

Since the subject is an instrument for assessment of educational qualification, in which the student performs care on an injured person, the teacher or mentor, when observing the care taken by the student in a real situation, will be able to assess the competencies and skills in the various categories of the composition of the checklist, as per Chart 1. 
Chart 1. Judges' opinions on the categories of composition of the checklist in Delphi round 1 and Delphi round 2, and competencies and skills evaluated by the instrument. Natal, RN, Brazil, 2013.

\begin{tabular}{|c|c|c|c|c|c|}
\hline \multirow[t]{2}{*}{ Categories of composition of the checklist } & \multicolumn{2}{|c|}{$\underset{(n=30)}{\text { Delphi } 1}$} & \multicolumn{2}{|c|}{$\begin{array}{c}\text { Delphi } 2 \\
(n=18)\end{array}$} & \multirow{2}{*}{ Competencies and skills } \\
\hline & Kappa & IVC & Kappa & IVC & \\
\hline $\begin{array}{l}\text { Initial observations } \\
\text { Preparation for care } \\
\text { Cleaning of hands }\end{array}$ & 0.76 & 0.87 & 0.87 & 0.93 & $\begin{array}{l}\text { Communication; } \\
\text { Obey biosafety rules; } \\
\text { Carry out procedures; } \\
\text { Deal with client }\end{array}$ \\
\hline \multicolumn{5}{|l|}{ Evaluation of the person and of the injury } & \multirow{9}{*}{$\begin{array}{c}\text { Communication; } \\
\text { Obey biosafety rules; } \\
\text { Carry out procedures; } \\
\text { Clinical reasoning; } \\
\text { Execute introductory techniques. }\end{array}$} \\
\hline Anamnesis & 0.78 & 0.87 & 0.85 & 0.91 & \\
\hline Physical examination & 0.73 & 0.84 & 0.85 & 0.91 & \\
\hline Identify risk factors & 0.74 & 0.85 & 0.86 & 0.92 & \\
\hline Verify vital signs & 0.78 & 0.88 & 0.88 & 0.93 & \\
\hline Evaluate pain & 0.77 & 0.87 & 0.88 & 0.93 & \\
\hline $\begin{array}{l}\text { Identify infection } \\
\text { in the wound }\end{array}$ & 0.76 & 0.85 & 0.89 & 0.94 & \\
\hline Assess the wound & 0.72 & 0.83 & 0.82 & 0.88 & \\
\hline $\begin{array}{l}\text { Identify tests needed, } \\
\text { and provide them }\end{array}$ & 0.82 & 0.90 & 0.88 & 0.93 & \\
\hline \multicolumn{5}{|l|}{ Care for the lesion and perilesional skin } & \multirow{4}{*}{$\begin{array}{l}\text { Obey biosafety rules; } \\
\text { Carry out procedures; } \\
\text { Clinical reasoning; }\end{array}$} \\
\hline Clean the wound & 0.65 & 0.78 & 0.78 & 0.87 & \\
\hline Bandaging & 0.66 & 0.78 & 0.72 & 0.83 & \\
\hline Evaluate need for debridement & 0.79 & 0.87 & 0.87 & 0.93 & \\
\hline Indicate coverage & 0.81 & 0.89 & 0.85 & 0.92 & Problem solving. \\
\hline \multicolumn{5}{|c|}{ Referral, and orientation of the person and family/carer } & \multirow{3}{*}{$\begin{array}{l}\text { Information and orientation; } \\
\text { Organization. }\end{array}$} \\
\hline Educational action & 0.85 & 0.91 & 0.85 & 0.91 & \\
\hline Refer patient & 0.84 & 0.91 & 0.80 & 0.88 & \\
\hline \multicolumn{5}{|l|}{ Registry and documentation } & \multirow{3}{*}{$\begin{array}{l}\text { Written communication; } \\
\text { Organization. }\end{array}$} \\
\hline Report clinical assessment & 0.81 & 0.89 & 0.85 & 0.91 & \\
\hline $\begin{array}{l}\text { Report assessment } \\
\text { of the wound }\end{array}$ & 0.82 & 0.89 & 0.84 & 0.91 & \\
\hline \multicolumn{5}{|l|}{ Final observations } & \multirow{3}{*}{$\begin{array}{l}\text { Obey biosafety rules; } \\
\text { Carry out procedures; } \\
\text { Organization. }\end{array}$} \\
\hline Organize care environment & 0.74 & 0.85 & 0.81 & 0.89 & \\
\hline Clean hands after providing care & 0.80 & 0.88 & 0.83 & 0.91 & \\
\hline
\end{tabular}

As to the requirements for evaluation of the instrument, it was found that the scores in the second round were higher in seven of the 10 items, and showed a statistical difference in the aspects relating to (i) being up to date with information, (ii) vocabulary, and (iii) pre- cision. This indicated that after the judges' suggestions the instrument was better structured, following practices based on more up-to-date evidence, using correct terms, and separating some items to avoid confusion and ambiguity (Chart 2).

Chart 2. Kappa, IVC and Wilcoxon test values for comparison of the indices of the checklist obtained in Delphi round 1 and Delphi round 2. Natal, RN, Brazil, 2013.

\begin{tabular}{|c|c|c|c|c|c|}
\hline \multirow[t]{2}{*}{ Evaluation characteristics } & \multicolumn{2}{|c|}{$\begin{array}{c}\text { Delphi } 1 \\
(n=30)\end{array}$} & \multicolumn{2}{|c|}{$\begin{array}{c}\text { Delphi } 2 \\
(n=18)\end{array}$} & \multirow{2}{*}{ p-value* } \\
\hline & Kappa & IVC & Kappa & IVC & \\
\hline Utility / relevance & 0.93 & 0.97 & 0.88 & 0.94 & 0.317 \\
\hline Consistency & 0.81 & 0.90 & 0.79 & 0.88 & 0.157 \\
\hline Clarity & 0.59 & 0.73 & 0.79 & 0.88 & 0.317 \\
\hline
\end{tabular}

continued... 
...continuation

\begin{tabular}{|c|c|c|c|c|c|}
\hline \multirow[t]{2}{*}{ Evaluation characteristics } & \multicolumn{2}{|c|}{$\begin{array}{c}\text { Delphi } 1 \\
(n=30)\end{array}$} & \multicolumn{2}{|c|}{$\begin{array}{c}\text { Delphi } 2 \\
(n=18)\end{array}$} & \multirow[t]{2}{*}{ p-value* } \\
\hline & Kappa & IVC & Kappa & IVC & \\
\hline Objectiveness & 0.81 & 0.90 & 0.79 & 0.88 & 0.317 \\
\hline Simplicity & 0.87 & 0.93 & 0.88 & 0.94 & 0.317 \\
\hline Feasible & 0.81 & 0.90 & 0.88 & 0.94 & 0.157 \\
\hline Up-to-date & 0.71 & 0.83 & 0.88 & 0.94 & 0.046 \\
\hline Vocabulary & 0.63 & 0.77 & 0.88 & 0.94 & 0.014 \\
\hline Precision & 0.71 & 0.83 & 0.88 & 0.94 & 0.046 \\
\hline Instructional sequence of the topics & 0.76 & 0.87 & 0.88 & 0.94 & 0.083 \\
\hline
\end{tabular}

*Wilcoxon test.

The results of the version prepared and validated by the use of the instrument of observation in evaluation of the nursjudges made it possible to set out a schematic explanation for ing care given to a person with a skin wound, as per figure 1 .

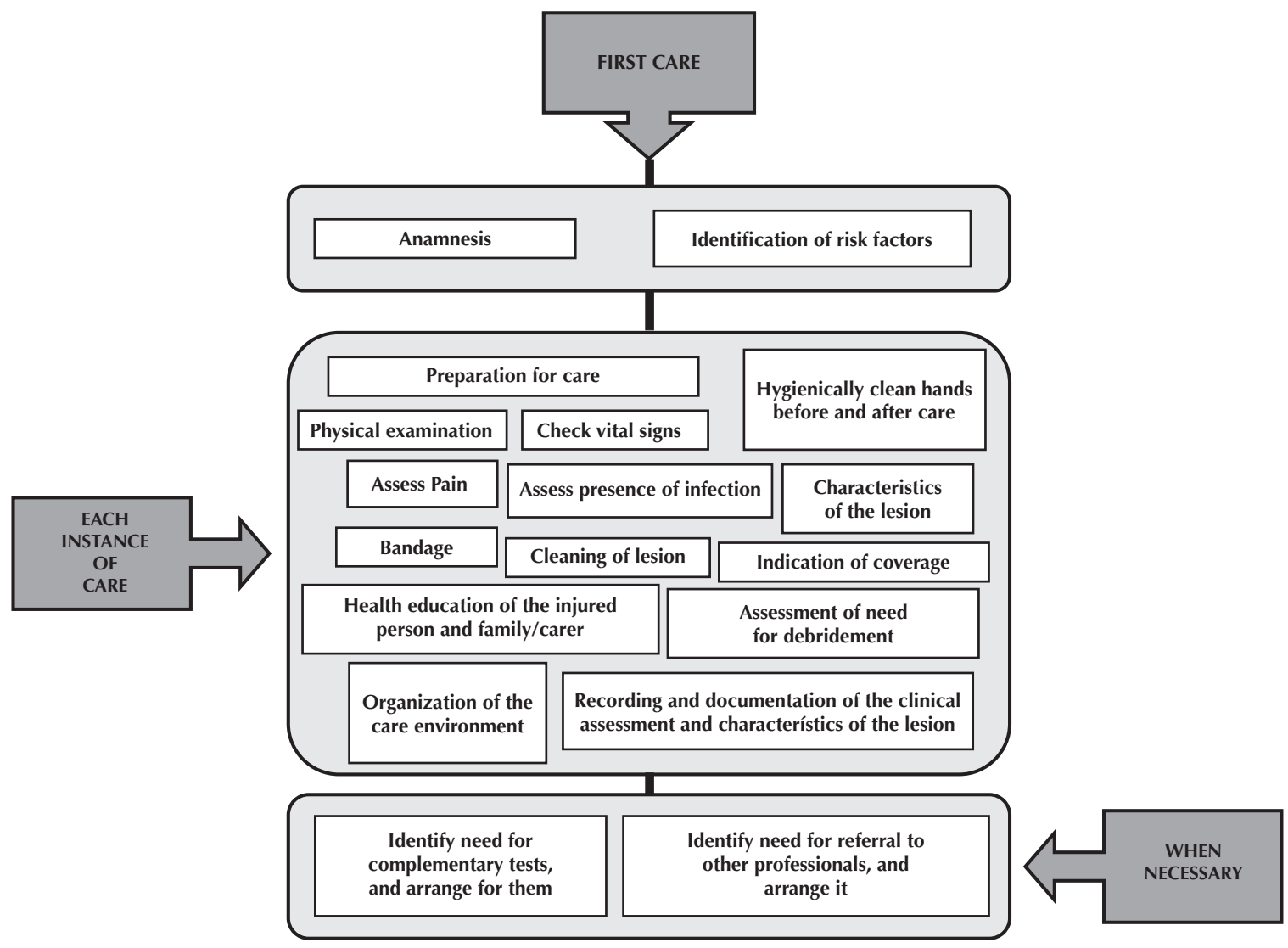

Figure 1. Diagram explaining the use of the instrument to evaluate care given by undergraduate nursing students to a person with a skin lesion. Natal, RN, Brazil, 2013.

The diagram proposed covers the aspects of nursing care given to a person with a skin injury, grouped by the need for realization, thus facilitating application of the instrument as a teaching resource to orient assessment of care given by undergraduate nursing students in real situations. While the student is providing care to a person with an injury, the examiner observes and records the student's performance in the evaluation exercise, identifying the competencies and skills that are shown to be good and those that still need more investment. Thus, this is a tool to be used in a teaching and learning on the subject.

\section{DISCUSSION}

The characteristics of the judges who took part in the study, evaluating the instrument relating to nursing care for a person with a skin injury, showed similarities in the first and second Delphi rounds. 
The time of experience in teaching and in healthcare reported by the judges in the two rounds of the Delphi technique showed professional experience with interaction between teaching and care capable of transforming and improving the processes of both learning and care ${ }^{(11)}$, and confirming the qualification of the participants of the study to consider the instruments used in the evaluation of care given by nursing undergraduates to a person with a skin lesion.

The Delphi technique has been widely used as a tool for validating content of investigations in the health area, with the objective of refining opinions and reaching a consensus between a group of specialists in a given subject, based on application of questionnaires in successive rounds, and using the feedback of information from the participants ${ }^{(5,12)}$.

Usually, the method adopted for obtaining consensus from a panel of judges is to carry out two or three rounds, depending on the nature and homogeneity of the group of participants and the complexity of the subjects studied ${ }^{(12)}$. The levels of consensus are chosen by the investigator and, according to the literature, can vary from 0.50 to 0.80 . Also, loss of participants is a fact expected at each round of the Delphi technique, although it is not a limiting factor for the analysis of the data of the investigation ${ }^{(12-13)}$.

In this study, the form for assessment of the checklist was submitted to the panel of specialists twice - in two rounds - with a lower number of participants in the second round. Improvement in the indices of agreement (CVI and Kappa) was obtained in the second round, after the reformulations resulting from feedback, and this was understood as evidence of validation of the instrument proposed.

We emphasize that the form submitted for the first round of opinions covered the aspects of care and the description of the parameter expected for its execution by the student in application of the checklist, but the procedures involved in the process of care did not include a detailed description of the technique. This initial configuration of the form influenced the Kappa and CVI values obtained, and supported the reformulations of the instrument for the second Delphi round. The increase in the indices of agreement between the judges from the first round to the second indicates refinement of the content of the instrument proposed.

It was seen that the majority of the items of the checklist obtained Kappa and CVI values higher than 0.80 , but the categories relating to cleaning of hands before provision of care, cleaning of the lesion, and bandaging did not reach this score, even though they presented an improvement in the level of consensus in the second Delphi round.

An increase in CVI was obtained in assessment of the item 'cleaning of hands before provision of care', an increase in the CVI was obtained in the second round of opinions, with statistical significance when the Wilcoxon test was applied to the Kappa values. The disagreements between the judges in relation to this item related to the description of the assessment parameter of the procedure to be carried out by the student, in relation to the need to divest personal adornments, and in the indication of need to carry out simple hygiene of the hands when they are visibly dirty.
The modification in the item about removal of 'divest adornments' in the description of the procedure of cleaning of hands was justified by the judges by relation to Regulatory Rule 32 (NR32), which specifies non-use of adornments by professionals in the environment of health institutions $^{(14)}$. The judges recognized that the literature describes the presence of dirt as one of the indications for carrying out hygiene of the hands ${ }^{(15)}$, but were opposed to keeping this stage in the description of the procedure, because they believed it causes confusion and has a negative influence on its realization by the student.

The items referring to cleaning of the wound and the technique of bandaging received the lowest indices of acceptance among the judges of this survey, although they presented a significant improvement in the Kappa and CVI values, higher than 0.80 , in the second Delphi round.

In these items, the description of the parameter to be assessed was questioned in relation to the use of irrigation of the wound with jets of $0.9 \%$ saline solution, with perforation of the flask with a $40 \times 12 \mathrm{~mm}$ needle - the shortage of scientific evidence on this practice being presented as a justification. Suggestions of improvements were also indicated: statement of requirement to use clean or sterile technique; and specifying the procedure to be carried out for wounds with primary, secondary or tertiary wound healing.

It is has been observed, indeed, that there is little literature, and of a low level, about the procedures and techniques involved in care for a person with a skin injury, such as cleaning and bandaging the wound. However, the technique described in the checklist, involving these procedures, is supported in the literature, principally in books and protocols for care of wounds ${ }^{(16-19)}$.

The shortage of standardized valid and reliable conducts favors use of different, divergent or conflicting practices in care of wounds by an interdisciplinary team. In the attempt to create a more efficacious and efficient intervention in the process of wound healing and in the quality of care given to the injured person, new technologies and instruments of evaluation are being created, validated and used in the field of treatment of wounds, facilitating systematic and detailed study of lesions, and also education of care teams, especially in the clinical context ${ }^{(20-21)}$.

The alterations suggested by the judges in the items that achieved a level of agreement lower than 0.80 were complied with or rejected after analysis and comparison with the literature. However it was decided not to remove the items that did not meet the Kappa or CVI index adopted (0.80), since there had been an increase in the level of agreement in the second round of opinions, and because of scores of above 0.80 in the criterion relating to the usefulness/ relevance of each item.

The category 'referral of the person with the skin lesion' was the only one among the 20 items in the composition of the checklist that showed a reduction in scores in the second round, in relation to the first Delphi round; but it remained within the Kappa and CVI values adopted.

The disagreements between judges in relation to this item were due to the absence of description, in that pa- 
rameter, of other professionals of the team to whom the injured person might possibly need to be referred; this description was included in the initial version of the checklist, submitted in the first Delphi round. Also, suggestions of improvements were made in terms of listing the more frequent minor complications, to give more consistency to the action recommended.

Referral for evaluation by specialists is fundamental in qualifying and completing the healthcare given to a person with a wound, and is necessary whenever evolution and reassessment indicate the need for the clinical examination and evaluation of the wound by other health professionals ${ }^{(22-23)}$.

However, since this is a case of an instrument for assessment of nursing care, and not of a multi-professional team, referral of the person with a wound to some health professionals ceases to be an attribution of the nurse, who, within his/her level of competence, should know how to identify the need for assessment of the patient by specialists and to arrange for a medical consultation, to request the referral ${ }^{(19)}$.

Usually, referrals to specialists (surgeons, endocrinologists, angiologists, infectious disease specialists, dermatologists, etc.) are made after the assessment by a doctor and discussion with the nursing team, with the exception of certain cases supported by healthcare protocols and rules established in some health services ${ }^{(24)}$.

In relation to the evaluation parameters of the checklists, it was found that the level of agreement of the judges in Delphi round 2 was higher in seven of the 10 parameters, which was understood to demonstrate evidence of validity of the instrument, according to the consensus reached between the specialists. Further, it is important to note that the agreement of the judges in the second Delphi round was greater in all the categories and parameters of evaluation of the instrument, but, with the adjustments involved in the calculation of the Kappa and CVI indices which were applied to the reduced sample of participants in the second round (18 judges), some of the scores were lower than, and/ or the same as those of the first Delphi round.

Further, it should be noted that compliance or noncompliance by the student with the requirements listed in the checklist will be evidence of the student's theoretical knowledge about the aspects of care for a person with a skin injury, but also of the acquisition of competencies and skills (humanistic, verbal and written communication, problem solving, organization, clinical reasoning and execution of techniques). In this regard, one should note its 'horizon- tal' importance. In other words, although certain skills and competencies are necessarily associated with specific tasks in care for an injured person, as presented in the checklist, they should not be limited to those tasks, but need to be mobilized by the student in other moments of the care being provided.

Summing up, it is observed that, in the final version, the instrument assessed by the judges was longer and less objective, but more complete, clear and consistent, covering activities, and description of their manner of execution, which are fundamental to the process of evaluation of the care provided by the undergraduate student to people with skin lesions.

\section{CONCLUSION}

The checklist proposed presented better scores in its component categories in the second Delphi round in relation to the Kappa and CVI scores of the first round.

In relation to the evaluation parameters, it was found that the agreement of the participants in the second round of the technique was greater in all the items, and this consensus of the judges was understood to indicate evidence of validity of the instrument, and its appropriateness for measurement of the care given by undergraduate nursing students to a person with a skin injury.

Measurement instruments based on scientific evidence provide a better-qualified assessment of the care being provided, and contribute to systematization of care in the training of students, and indeed even of professional nurses.

It is understood to be the case that the construction of reliable instruments of measurement is important for nursing and can provide elements supporting identification of deficiencies, and the taking of measures to resolve the failures identified. It is important to provide safe and good-quality care for patients with injuries, and overcome the dichotomy between theory and practice in the training of professionals to face problem situations.

The Delphi technique used for evaluating the checklist made it possible to refine the opinions and to achieve a consensus of the judges in relation to care of the person with a skin lesion, including standardization of essential conducts to be evaluated systematically in measurement of the performance of the undergraduate student.

However, more surveys are necessary to confirm the validity and reliability of this instrument. The second step should be the application of this checklist in clinical scenarios of teaching-learning, to assess their contributions to the public for which they are intended.

\section{RESUMO}

Objetivo: Apresentar o processo de construção e validação de um instrumento para avaliar o cuidado à pessoa com ferida para aplicação com graduandos de enfermagem. Método: Pesquisa metodológica, quantitativa, com aplicação da técnica Delphi em duas rodadas. A primeira com 30 juízes e a segunda com 18. A análise foi feita com o coeficiente Kappa $\geq 0,80$, o índice de validade de conteúdo $>0,80$, além do teste de Wilcoxon para comparações dos índices entre as rodadas. Resultados: Verificou-se que, das 20 categorias do instrumento, 18 apresentaram melhores escores na fase Delphi 2. Quanto aos requisitos de avaliação, constatou-se que os escores na segunda fase foram maiores em sete dos 10 itens. Conclusão: A partir da avaliação dos juízes, foi definida uma versão do instrumento com índices de concordância e validade adequados, que poderá contribuir com a avaliação do cuidado de graduandos de enfermagem à pessoa com lesão cutânea. 


\section{DESCRITORES}

Ferimentos e Lesões; Cuidados de Enfermagem; Estudos de Validação; Estudantes de Enfermagem.

\section{RESUMEN}

Objetivo: Presentar el proceso de construcción y validación de un instrumento para evaluar el cuidado a la persona con herida a fin de aplicarlo a los graduandos de enfermería. Método: Investigación metodológica, cuantitativa, con aplicación de la técnica Delphi en dos rondas. La primera con 30 jueces y la segunda con 18 . El análisis se hizo mediante el coeficiente Kappa $\geq 0,80$, el índice de validez de contenido $>0,80$, además de la prueba de los rangos con signos de Wilcoxon para comparaciones de los índices entre las rondas. Resultados: Se verificó que, de las 20 categorías del instrumento, 18 presentaron mejores puntajes en la fase Delphi 2. En cuanto a los requisitos de evaluación, se advirtió que los puntajes en la segunda fase fueron mayores en siete de los 10 ítems. Conclusión: Desde la evaluación de los jueces, se definió una versión del instrumento con índices de concordancia y validez adecuados, la que podrá contribuir con la evaluación del cuidado de graduandos de enfermería a la persona con lesión cutánea.

\section{DESCRIPTORES}

Herydas y Traumatismos; Atención de Enfermería; Estudios de Validación; Estudiantes de Enfermería.

\section{REFERENCES}

1. Waidman MAP, Rocha SC, Correa JL, Brischiliari A, Marcon SS. O cotidiano do indivíduo com ferida crônica e sua saúde mental. Texto Contexto Enferm. 2011;20(4):691-9.

2. Yamada BFA, Santos VLCG. Development and validation of Ferrans \& Powers Quality of Life Index: wound version. Rev Esc Enferm USP [Internet]. 2009 [cited 2014 July 9];43(n.spe):1105-13. Available from: http://www.scielo.br/pdf/reeusp/v43nspe/en_a15v43ns.pdf

3. Dantas DV, Torres GV, Dantas RAN. Assistência aos portadores de feridas: caracterização dos protocolos existentes no Brasil. Ciênc Cuid Saúde. 2011; 10(2):366-72.

4. Torres GVT, Mendes FRP, Mendes AFRF, Silva AO, Torres SMSGSO, Viana DMO, et al. Nurses' evaluation about primary health care of users with venous ulcers: study in Évora, Portugal. Rev Enferm UFPE on line [Internet]. 2011 [cited 2014 July 9]; 5(n.spe):388-98. Available from: http://www.revista.ufpe.br/revistaenfermagem/index.php/revista/article/viewArticle/1731

5. Bittencourt HR, Creutzberg M, Rodrigues ACM, Casartelli AO, Freitas ALS. Desenvolvimento e validação de um instrumento para avaliação de disciplinas na educação superior. Est Aval Educ [Internet]. 2011 [citado 2014 jul. 9];22(48):91-114. Disponível em: http://educa.fcc. org.br/pdf/eae/v22n48/v22n48a06.pdf

6. Kuwabara CCT, Évora YDM, Oliveira MMB. Risk management in technovigilance: construction and validation of a medical-hospital product evaluation instrument. Rev Latino Am Enfermagem [Internet]. 2010 [cited 2014 July 9];18(5):943-51. Available from: http://www.scielo. br/pdf/rlae/v18n5/15.pdf

7. Randolph JJ. Online Kappa calculator [Internet]. 2008 [cited 2013 Sept 25]. Available from: http://justus.randolph.name/kappa

8. Fonseca R, Silva P, Silva R. Acordo inter-juízes: o caso do coeficiente Kappa. Lab Psicol [Internet] 2007 [citado 2013 set. 25];5(1):81-90. Disponível em: http://repositorio.ispa.pt/bitstream/10400.12/1263/1/LP\%205\%281\%29\%2081-90.pdf

9. Alexandre NMC, Coluci MZO. Validade de conteúdo nos processos de construção e adaptação de instrumentos de medidas. Ciênc Saúde Coletiva. 2011;16(7):3061-68.

10. Brasil. Ministério da Saúde; Conselho Nacional de Saúde. Resolução no 466, de 12 de dezembro de 2012. Dispõe sobre as diretrizes e normas regulamentadoras de pesquisas envolvendo seres humanos [Internet]. Brasília; 2012 [citado 2013 set. 25]. Disponível em: http:// conselho.saude.gov.br/resolucoes/2012/Reso466.pdf

11. Reibnitz KS, Daussy MFS, Silva CAJ, Reibnitz MT, Kloh D. Rede Docente Assistencial UFSC/SMS de Florianópolis: reflexos da implantação dos projetos Pró-Saúde I e II. Rev Bras Educ Med [Internet]. 2012 [citado 2014 jul. 9];36(1):68-75. Disponível em: http://www.scielo.br/ $\mathrm{pdf} / \mathrm{rbem} / \mathrm{v} 36 \mathrm{n} 1 \mathrm{~s} 2 / \mathrm{a} 11 \mathrm{v} 36 \mathrm{n} 1 \mathrm{~s} 2 . \mathrm{pdf}$

12. Scarparo AF, Laus AM, Azevedo ALCS, Freitas MRI, Gabriel CS, Chaves LDP. Reflexões sobre o uso da técnica Delphi em pesquisas na enfermagem. Rev RENE [Internet]. 2012 [citado 2014 jul. 9];13(1):242-51. Disponível em: http://www.revistarene.ufc.br/revista/index. php/revista/article/download/36/31

13. Fernandes IR, Tilbery CP, Avelar MCQ. Validação das condutas de enfermagem na orientação de clientes com esclerose múltipla em uso de imunomoduladores. Rev Neurocienc. 2011;19(1):68-76.

14. Brasil. Ministério do Trabalho e Emprego. Portaria GM n. 485, de 11 de novembro de 2005. Aprova a norma regulamentadora ${ }^{\circ} 32$ (Segurança e Saúde no Trabalho em Estabelecimentos de Saúde) [Internet]. Brasília; 2005 [citado 2013 set. 27]. Disponível em: http://sbbq. iq.usp.br/arquivos/seguranca/portaria485.pdf

15. Brasil. Ministério da Saúde; Agência Nacional de Vigilância Sanitária. Anexo 1: Protocolo para a prática de higiene das mãos em Serviços de Saúde [Internet]. Brasília; 2013 [citado 2013 set. 27]. Disponível em: http://www.sbpc.org.br/upload/conteudo/protocolo_higiene_ maos_09jul2013.pdf

16. Santos AAR, Medeiros ABA, Soares MJGO, Costa MML. Avaliação e tratamento de feridas: o conhecimento de acadêmicos de enfermagem. Rev Enferm UERJ. 2010;18(4):547-52.

17. Borges EL, Saar SRC, Magalhães MBB, Gomes FSL, Lima VLAN. Feridas: como tratar. $2^{\text {a }}$ ed. Belo Horizonte: Coopmed; 2008.

18. Ferreira AM, Andrade D. Integrative review of the clean and sterile technique: agreement and disagreement in the execution of dressing. Acta Paul Enferm. 2008;21(1):117-21. 
19. Ribeirão Preto. Secretaria Municipal da Saúde. Programa de Educação Continuada. Manual de assistência integral as pessoas com feridas crônicas [Internet]. Ribeirão Preto; 2011 [citado 2013 set. 25]. Disponível em: http://www.ribeiraopreto.sp.gov.br/ssaude/programas/sad/ manual_feridas_2011.pdf

20. Zhong X, Nagase T, Huang L, Kaitani T, lizaka S, Yamamoto Y, et al. Reliability and validity of the chinese version of DESIGN-R, an assessment instrument for pressure ulcers. Ostomy Wound Manage. 2013;59(2):36-43.

21. Thompson N, Gordey L, Bowles H, Parslow N, Houghton P. Reliability and validity of the revised photographic wound assessment tool on digital images taken of various types of whronic wounds. Adv Skin Wound Care. 2013;26(8):360-73.

22. Morais GFC, Oliveira SHS, Soares MJGO. Avaliação de feridas pelos enfermeiros de instituições hospitalares da rede pública. Texto Contexto Enferm. 2008;17(1):98-105.

23. Moreira RAN, Queiroz TA, Araújo MFM, Araújo TM, Caetano CA. Condutas de enfermeiros no tratamento de feridas numa unidade de terapia intensiva. Rev RENE. 2009;10(2):45-51.

24. Belo Horizonte. Secretaria Municipal de Políticas Sociais; Secretaria Municipal de Saúde, Coordenação de Atenção à Saúde do Adulto e do Idoso. Protocolo de assistência aos portadores de feridas [Internet]. Belo Horizonte; 2006 [citado 2013 set. 25]. Disponível em: http:// www.pbh.gov.br/smsa/biblioteca/atadulto/protocoloferidas.pdf 